\title{
Preparing the way for a modern GST in India
}

\section{Sijbren Cnossen}

\begin{abstract}
A modern Goods and Services Tax (GST) would do much to alleviate the problems of India's current indirect tax system which is a serious impediment to the formation of a single common market and further economic growth. The Centre and the States should both have access to the full GST base, which means that the tax assignment issue (who should tax what?) should be separated from GST design aspects (what should be the precise base and rate structure?). It is not necessary or desirable to have a uniform GST for the Centre and the States. Neither is an integrated GST to tax transactions between States required. Last but not least, the system of taxation by classification and valuation should be replaced by a self-assessment system mainly monitored through checks upon books of account.
\end{abstract}

Keywords India $\cdot$ GST $\cdot$ VAT $\cdot$ Tax assignment

This article is based on the author's presentation at a conference on Emerging Issues in Public Finance and Policy held at the Centre for Studies in Social Sciences, Calcutta, February 23-24, 2012, and on the paper presented at the 68th Annual Congress of the International Institute of Public Finance, held at Dresden, August 13-16, 2012.

S. Cnossen $(\bowtie)$

CPB Netherlands Bureau for Economic Policy Analysis, P.O. Box 80510, 2508 GM, The Hague, The Netherlands

e-mail: cnossen@ese.eur.nl

S. Cnossen

University of Pretoria, Pretoria, South Africa

S. Cnossen

Erasmus University Rotterdam, Rotterdam, The Netherlands

S. Cnossen

University of Maastricht, Maastricht, The Netherlands 


\section{Archaic, irrational and complex tax system ${ }^{1}$}

The Indian Constitution assigns the power to levy 'duties of excise on goods manufactured in India', 'tax on services', and 'duties of excise on tobacco' to the federal government, called the Centre. Consequently, the Centre levies an extended system of excise duties at the manufacturers' level, since the Constitution does not allow its extension through to the retail level. This system is called Central Value added Tax or CENVAT, for short, because the tax on inputs (except, obviously, inputs of downstream wholesalers and retailers) is allowed to be credited against the tax on output. To forestall margin shifting, presumptive retail values are imputed to taxable consumer products, which involves pernicious and contentious definition and valuation issues. In addition, the Centre's tax on services is not fully integrated with the taxation of goods.

The States have been given the power to impose 'taxes on the sale and purchase of goods', 'excise duties on alcohol', and taxes on betting and gambling, mineral rights, vehicles, transport and luxury goods. At the State level, ${ }^{2}$ some progress has been made with the introduction of value-added taxes (VATs), but unfortunately the Constitution implies that services cannot be included in the base. Further, interstate exports are subject to Central Sales Tax (CST), an origin-based levy collected and kept by the State in which the sale originates. Beyond this, the States and the Centre both collect a vast array of revenue and stamp duties, which resemble cascading turnover taxes. It may be surmised that, without reason, the effective tax burden on various goods and services varies widely across products and across India. ${ }^{3}$

Although the Constitution provides for freedom of trade and commerce throughout the territory of India (Article 301), the system of indirect taxation at the central and state levels is a serious obstacle to the formation of a single common market in which businesses source anywhere, manufacture anywhere and sell anywhere. Its complexity is baffling and its incidence highly capricious and indeterminate. The system's multiple tax-on-tax effects cascade throughout the production-distribution chain with harmful economic consequences. These effects are compounded by the lack of coordination between the various forms of indirect taxation (sales taxes, excise duties, import duties) and between the different levels of government (Centre vs. States, States vs. other States). The CST, moreover, violates the common market principle, which prescribes that goods and services should be taxed in the State

\footnotetext{
${ }^{1}$ The words between quotation marks are from the Bagchi et al. report (1994, p. xvii) on the Indian indirect tax system. The author was a consultant to the Bagchi team.

${ }^{2}$ Throughout this article, references to 'States' should be deemed to include 'Union Territories'.

${ }^{3}$ For a general discussion of the need for reform of the Indian tax system, see Rao and Rao (2010) and for an extended description and analysis of the ills of the indirect taxes, see Cnossen (2012).
} 
of consumption or end-use. Last but not least, the enforcement of the respective tax administrations is highly uneven. ${ }^{4}$

Many expert analyses have been made of the system's shortcomings but so far no real breakthrough has been achieved. The Empowered Committee of State Finance Ministers $(2005,2009)$ charged with the reform process, the Thirteenth Finance Commission (2009) and various think tanks and scholars have written superb reports on the design of a modern Goods and Services Tax (GST). ${ }^{5}$ Most proposals call for the introduction of a broad-based dual GST, levied concurrently by the Centre (CGST) and each of the States (SGST). Most reports come out in favor of identical CGST and SGST bases, although (single) rates (with minimal exemptions) might differ between States. Most reports also opine that the taxes should be independently administered, although it would be worthwhile to pursue uniformity of assessment and collection procedures.

\section{Separation of tax assignment and GST design required}

As the discussions between the Centre and the States evolve, there appears to be agreement that services should be included in the GST base on a comprehensive basis. But the States insist that petroleum products, immovable property, electricity and alcohol, which are important sources of revenue for them, should be left out of the GST base, although this would seriously jeopardize the efficiency gains of the reform. Clearly, this is a case in which the tax assignment issue (called empowerment in India) — who should tax what? - has become entangled with GST design aspectswhat should be the precise base and rate structure?- to the detriment of sound tax policy. In my view (and that of others), the only way out of this dilemma is to separate the two issues. ${ }^{6}$ Both the Centre and the States should be allowed to tax all goods and services under their GSTs, including imports and excisable goods. This would best serve equal treatment, economic efficiency and administrative feasibility. After that, the Centre and the States could impose their own excises on smoking, drinking, gambling, polluting and driving - activities that exhibit external costs, which should be internalized in price through appropriate excise taxes and which are lucrative sources of revenue. ${ }^{7}$ The two levels of government could also reach agreement regarding the

\footnotetext{
${ }^{4}$ That State VATs are in need of reform is echoed in the report of the Thirteenth Finance Commission $(2009$, p. 2), which observes that 'the VAT, like its predecessor the Sales tax, continues to be characterised by narrow base, plethora of exemptions, multiple rate structure and cascading effect on account of break in the input-credit chain. The introduction of VAT is, at best, a toddler's tentative step towards indirect tax reform'.

${ }^{5}$ In India, the term Goods and Services Tax (GST) is used for the broad-based consumption tax proposed for the Centre (CGST) and the States (SGST), while the consumption taxes of the States are called VATs. As is well known, a VAT is in principle identical to a GST, but this article adheres to the terminology used in India. For the reports, see, among others: Chelliah et al. (1992-1993), Kelkar et al. (2002), and Poddar and Ahmad (2009). Much early pioneering work was done by a team under the able leadership of Amaresh Bagchi and laid down in Bagchi et al. (1994).

${ }^{6}$ In fact, I believe that it would be better to postpone the introduction of the dual GST than to try to design it without straightening out the tax assignment issue.

${ }^{7}$ For a thorough review of excise taxes on smoking, drinking, gambling, polluting, and driving, see the contributions in Cnossen (2005).
} 
excisable goods that should be taxed by the States and those that might be left in the Centre's tax domain.

Separation of the tax assignment question from GST design issues would enable the Centre and State governments to have full access to a modern GST. Its hallmarks are a broad base with the fewest possible exemptions, a single rate, a sizable threshold and tax collection in the jurisdiction of consumption (States for their SGST, the Centre for its nationwide CGST). In principle, exemptions should be limited to government administration, health, education, residential rents and sales of used residential premises, and non-fee based financial services. The threshold should be at least INR 40 lakh (US\$ 74,000) and possibly as high as INR 50 lakh (US\$ 92,000). Experience elsewhere indicates that the cost in forgone revenue would be small, because exempt small businesses would still pay GST on inputs. A high threshold would permit the GST administrations to concentrate on the 'big fish,' which, as a rule of thumb, contribute at least 80 percent of GST revenue, although they represent 20 percent or less of all GST registrants.

Unprocessed foodstuffs should be taxed, I believe, but the subsidy on publicly distributed foodstuffs could be increased to compensate the poor for the increase in price. If this is not possible, exemption, perhaps in conjunction with the zerorating of selected agricultural inputs, would be preferable to a zero rate on foodstuffs. In theory, the result might not seem as neat as under zero-rating, but in practice it would be very similar. However, administration and compliance costs would be much lower under the exemption approach. Exemption might also be more of a deterrent to political pressures to increase the number of favored products. Exemption is the route that most countries at a similar level of economic development as India have taken, although providing relief to the poor through exemptions (or zero rates) is likely to be both unsound tax policy and ineffective social policy.

The case for a broad-based GST deserves to be emphasized. It is widely agreed that a GST should not be used to influence the distribution of the tax burden (for which the income tax, the social benefit system and perhaps selected excise taxes on luxury goods are more appropriate instruments), to protect domestic industry (for which import duties should be used, if at all), to favor labor-intensive production processes over capital-intensive processes (which, again if desirable, can be done through income taxes), to promote economic development (which, as has been demonstrated, cannot be stimulated through the tax system (Zee et al. 2002)) or for any other 'worthy' socioeconomic goal. The GST is simply a revenue-raising instrument which can be used to finance socially and economically desirable expenditures.

\section{Uniformity of Centre GST and State GSTs not necessary or desirable}

In contrast to other recommendations, I do not believe that the tax bases (and procedures, forms and methods) of the Centre's GST and the GSTs of the various States should be identical. Although this might minimize conflict, ease interpretation issues and generally make GST life easier for registrants, the aim ignores the fact that States have already introduced their own VATs, different from each other, and, perhaps more importantly, that best-practice GSTs should differ from one State to another. States 
whose economy is mainly agricultural will want a somewhat different GST from States whose economy is largely industrial. States that have a well-organized trade sector can perhaps do with a somewhat lower threshold than States with many small establishments. Further, the most effective GST in States with wide-scale evasion will be different from that in States with a high level of tax compliance. In my view, some diversity (which is not the same as a free for all) would still be consistent with a common market if care is taken that interstate exports are freed of SGST.

Identical GSTs might also lock the Centre and the States into a system that would become undesirable over time, but which would de facto be subject to a unanimity requirement like the European Union's (EU's) common VAT directive. The EU's directive has not been changed since 1977 and is in danger of becoming an anachronism. Instead, the Centre should endeavor to design and implement a fully modern GST modeled after, say, the New Zealand and South African GSTs. Following the resolution of the tax assignment issue, therefore, the Centre should proceed to introduce its own GST on as broad a base as possible and apply a single, uniform, low rate of, say, 5 percent. It would then be up to the States to introduce a similar GST, piggyback their GST on to the Centre's GST (in other words, ask the Centre to collect the SGST for them) or retain their current (modified) VAT. $^{8}$

This is exactly the way the constitutional logjam was addressed in Canada. After an abortive attempt to harmonize the federal manufacturers' sales tax and the provincial retail sales taxes (RSTs), the federal government went ahead and introduced its own broad-based GST. Subsequently, Québec adopted its own independently administered GST (called Québec Sales Tax, or QST) based on the federal example (it also collects the federal GST and transfers the proceeds to Revenue Canada). Three Atlantic Provinces and Ontario, to be followed this year by Prince Edward Island, decided to piggyback the federal GST in the form of a surtax whose rate is set by individual provinces but which is collected by the federal GST administration. This tax is called the Harmonized Sales Tax (HST); its revenue is allocated to the HST provinces on the basis of consumption statistics. Thus, interprovincial exports do not have to be zero rated, unlike exports from Québec, whose inputs have been subject to its provincial GST. Three provinces have retained their RST (including British Columbia which briefly flirted with the HST), while oil-rich Alberta stayed out of the GST/HST/RST game altogether. This arrangement provides maximum taxing autonomy for the provinces (particularly Québec), does not interfere with interprovincial trade (there is no IGST) and minimizes (extra) administrative and compliance costs (particularly for HST provinces)—all under the compliance-control umbrella of the federal GST (Bird and Gendron 2010; Smart and Bird 2012).

\footnotetext{
${ }^{8}$ The Comptroller and Auditor General of India (2010, p. v) observes that there are 'wide scale differences between the basic design proposed in the White Paper [of the Empowered Committee of State Finance Ministers] and the corresponding provisions included in the different State VAT Acts and Rules.'
} 


\section{Integrated GST to tax inter-State transactions not necessary}

Free trade and free competition in the Indian common market can best be ensured by collecting the GST on a destination basis, i.e. in the State of consumption. Interstate exports would then be zero rated and interstate imports taxed on a par with in-Stateproduced goods and services. But without some form of monitoring system, it is argued, exports from one State to another (zero rated for the SGST, not for the CGST) might be diverted to the exporting State's local market, while imports might not be reported for SGST purposes. To keep a check on interstate trade, it has been proposed, therefore, to levy the full SGST (in addition to the CGST) on interstate exports under what is called the Integrated GST (IGST). Exporters would collect the IGST from importers and pay the tax to the Centre, which in turn would refund the destinationState for the SGST credit allowed to importers. In essence, therefore, the IGST would not raise any revenue but would solely be used to monitor interstate trade through an automated reporting and verification process administered by a central clearing agency. At least nine models have been proposed to track payments and refunds. ${ }^{9}$

A similar proposal, called Compensating VAT (CVAT), has been made in the tax literature. ${ }^{10}$ Under the CVAT, interstate trade (zero rated under State VATs) would be subject to an export tax administered by a central agency, which would use the revenue to finance an equivalent tax rebate on imports. Essentially, the CVAT, if projected on the Indian situation, would tackle the problem of fraudulent export and import invoices for the State VAT administrations by performing audits at the central level through a charge-and-refund system. Another, similar, proposal, called Viable Integrated VAT (VIVAT), ${ }^{11}$ was proposed in the tax literature for the EU situation but never adopted. Under the VIVAT, a uniform tax would be imposed on all intermediate (non-retail) transactions between VAT-registered traders within and between member states. Interstate exporters would be taxed and interstate importers would be allowed a credit at the same uniform rate. A clearing mechanism would be installed for payments from net exporting states to net importing states, based on export and import statistics, with the revenue allocated to member states on the basis of consumption statistics.

It has been argued, however, that VIVAT does not repair the break in the VAT audit trail in the EU, which seems to be the real problem (Cnossen 2010). Instead of fraudulent export invoices (to get refunds), VAT administrations would be faced

\footnotetext{
${ }^{9}$ Some reports believe that a dual GST should deal with the problem of non-arm's-length transactions between branches of the same business, for instance. However, under a properly administered CGST transfer pricing issues would not arise because any 'under-' or 'over-taxation' would be automatically corrected in subsequent stages of production or distribution through a lower or higher tax credit.

${ }^{10}$ See McLure (2000), who acknowledges that his proposal is based on an idea launched earlier for the Brazilian states by Ricardo Varsano. It should be noted that McLure's proposal is limited to cross-border transactions in goods. Accordingly, it would have to be tailored to handle services under some kind of reverse-charging mechanism (imports declared by first in-State recipient), which raises the question of why goods should not also be taxed under the same mechanism.

${ }^{11}$ The high-profile proposal was developed by Keen and Smith (1996). See also Crawford et al. (2010). Note that the VIVAT, unlike the CVAT, was proposed for an EU context in which there is no higher level of government. The Indian situation, like the Canadian, is that of the CVAT with an overarching central administration.
} 
with fraudulent import invoices (to get credits). In the event, it might be better to establish bilateral or multilateral audit agencies in the EU, which could monitor, investigate and, if necessary, submit for prosecution, cross-border fraud cases. ${ }^{12}$ Of course, CVAT performs cross-border audits, but then the question is why this needs to be done under the aegis of a no-revenue-raising tax.

In India, by contrast, there already would be a central audit agency, in the form of the CGST administration, which can monitor interstate transactions. Essentially, GST fraud with respect to interstate transactions-or in-State ones, for that matter-should be detected through well-designed audit programs based on risk assessments, selective cross-checking, intelligence gathering and targeted fraud investigation. States can then continue to zero-rate exports. In the event, getting a refund for the GST would solely be a matter between the in-State business and its government. In essence, there is no break in the GST collection chain (the CGST would still be applied), but only in the State cross-border audit trail, a break that is repaired by the Centre's nationwide audit trail, as in Canada. The CGST is the common thread that binds interstate transactions. Why spin another one?

Although an IGST does not seem necessary (and would increase administrative and compliance costs), it would be advisable to design appropriate place-of-supply rules under which GST-registered recipients of out-of-State goods and services would be obliged to report their out-of-State purchases, charge GST on them and permit themselves a credit at the same time. (This reverse-charge mechanism should also be put in place for services rendered from abroad.) Further, to be able to remove physical border checks between States, the SGSTs should probably stipulate that 'big-ticket' items, such as motor vehicles, boats and airplanes, should be taxed in the State of registration, that mail-order firms should charge and remit the SGST of the destination State, and that exempt entities should report their out-of-State purchases, which would be taxable in the destination State. Under this arrangement, cross-border consumer purchases would be taxed on an origin basis, but that is the price to be paid for the removal of State border controls.

\section{Concluding comments}

India is at a crucial crossroads in its fiscal history. Following years of having to make do with archaic systems of excise duties and sales taxes, it now has the opportunity to introduce a modern GST at the central and state levels. There are more than 150 countries with a GST or VAT around the world from which to learn. Some of these countries, such as New Zealand, Australia, Canada, Singapore and South Africa, have good GSTs with broad bases and (nearly) uniform rate structures. Other countries,

\footnotetext{
${ }^{12}$ In a recent Communication on the issue (COM (2011) 851), the European Commission indicates that it will pursue the establishment of cross-border audit units. Interestingly, in Europe, the mismatches, mostly non-fraudulent, between returns for interstate exports and returns for imports totaled $€ 80$ billion in 2006 (involving $€ 12$ billion VAT revenue, calculated at the EU-wide agreed minimum standard rate of 15 percent), while the major exporting states would have to pay some $€ 30$ billion VAT to importing states (something which, no doubt, they would not do wholeheartedly). (For the figures, see Cnossen 2010.) This does not augur well for the automated interstate processing and verification system envisaged for India.
} 
such as the member states of the European Union, have bad VATs with many exemptions and multiple rates. Still other countries-Brazil is an example-have ugly VATs with a manufacturing-stage VAT at the federal level (similar to India's CENVAT), origin-based VATs (exports taxed, imports not taxed) at the state level, and separate taxation of goods and services. Choosing an ugly GST over a good GST could easily cost India at least 1-2 percent of national income due to unwarranted administrative and compliance costs, and avoidable economic distortions. ${ }^{13}$

Perhaps the negotiations between the Centre and the States over the most appropriate GST have started at the wrong end of the issue-i.e. the tax base-whereas the right end is the intergovernmental assignment issue. Both the Centre and the States should be interested in the broadest possible base. This implies that petroleum products, electricity, alcohol, immovable property, tobacco and most foodstuffs should all be in the GST base. Leaving these goods out of the base has serious distortionary consequences (because of the denial of GST input tax credits, with subsequent cascading effects) and would greatly complicate administration and compliance (because of the need to allocate input GST between exempt and taxable transactions). Likewise, services should be taxed comprehensively and not be the subject of enumeration (called a positive list in India), which may involve contentious legal issues and distort economic decisions. Admittedly, adopting the broadest possible base (by both the Centre and the States) may raise uncertainties about prospective revenue yields, but these can be addressed through vertical revenue guarantee and compensation mechanisms similar to the schemes agreed to at the time the State VATs were introduced.

Last but not least, GST compliance control differs from CENVAT control. CENVAT is about classification and valuation: defining manufactured goods by reference to some nomenclature, imputing a presumptive retail value to them and applying the tax rate. But this excise tax approach to assessment and collection is a world apart from the audit approach under the GST. Under the GST, the tax would be based on actual, not presumptive, prices and compliance control would be exercised through checks on books of account. In other words, auditors are needed, not excise tax officers. Auditors are familiar with flow-of-funds analysis, net worth statements and cross-checks between the entries in the books of one company and the entries made by another company. By contrast, excise officials are more akin to customs staff, who inspect goods, classify them and appraise their value for import duty purposes. Emphatically, the new GST needs an accounting approach, not excise tax methods, for compliance control and enforcement. In terms of compliance control, the GST is akin to the business income tax, and thus it would be advisable to maintain close liaison with the income tax department at the central level. The implications of this profound change in organization and methods should not be lost on policymakers.

Acknowledgements The author is grateful for the comments received from Michael Keen, Judith Payne and two anonymous referees. He has also greatly benefited from discussions about the Indian tax system with Satya Poddar, Govinda Rao and Partho Shome, but he alone should be held responsible for the end product.

\footnotetext{
${ }^{13}$ I base this estimate on the calculations of the Thirteenth Finance Commission (2009, p. xv), which expects the gains to India's GDP of a modern GST to lie in the range 0.9-1.7 percent. In my view, this gain, and hence the cost of continuing with the present system, is on the low side.
} 


\section{References}

Bagchi, A., et al. (1994). Reform of domestic trade taxes in India: issues and options (Report of a Study Team). New Delhi: National Institute of Public Finance and Policy.

Bird, R. M., \& Gendron, P.-P. (2010). Sales taxes in Canada: the GST-HST-QST-RST 'system'. Tax Law Review, 63(3), 517-582.

Chelliah, R. J., et al. (1992-1993). Report of the tax reforms committee-I\&II. In Reports of India's tax reforms. New Delhi: Academic Foundation.

Cnossen, S. (Ed.) (2005). Theory and practice of excise taxation: smoking, drinking, gambling, polluting, and driving. Oxford: Oxford University Press.

Cnossen, S. (2010). VAT coordination in common markets and federations: lessons from European experience. Tax Law Review, 63(32), 583-622.

Cnossen, S. (2012). Introducing a modern GST in India: need for further debate. Tax Notes International, June 25, 1267-1283.

Comptroller and Auditor General of India (2010). Implementation of value added tax in India: lessons from transition to goods and services tax — a study report. New Delhi (June).

Crawford, I., Keen, M., \& Smith, S. (2010). Value added tax and excises. In J. Mirrlees et al. (Eds.), Dimensions of tax design: the Mirrlees review.

Empowered Committee of State Finance Ministers (2005). First discussion paper on goods and services tax in India, New Delhi (November 10).

Empowered Committee of State Finance Ministers (2009). A white paper on state-level value added tax. New Delhi (January 17).

Keen, M. (2009). What do (and don't) we know about the value added tax? A review of Richard M. Bird and Pierre-Pascal Gendron's The VAT in developing and transitional countries. Journal of Economic Literature, 47(1), 159-170.

Keen, M., \& Smith, S. (1996). The future of value added tax in the European Union. Economic Policy, 23, $373-420$.

Kelkar, V. L., et al. (2002). Report of the task force on indirect taxes. In Reports of India's tax reforms. New Delhi: Academic Foundation.

McLure, C. E., Jr. (2000). Implementing subnational value added taxes on internal trade: the compensating VAT (CVAT). International Tax and Public Finance, 7(6), 723-740.

Poddar, S., \& Ahmad, E. (2009). GST reforms and intergovernmental considerations in India (Working Paper No. 1/2009-DEA). New Delhi: Department of Economic Affairs, Ministry of Finance, Government of India.

Rao, G. M., \& Rao, R. K. (2010). Tax reform in India. In R. Gordon \& J. Stiglitz (Eds.), Taxation in developing countries: six case studies and policy implications. New York: Columbia University Press. Chap. 4.

Smart, M., \& Bird, R. (2012). VAT in a federal system: lessons from Canada. University of Toronto, unpublished.

Thirteenth Finance Commission (2009). Report of the task force on goods \& services tax (December 15).

Zee, H. H., Stotsky, J. G., \& Ley, E. (2002). Tax incentives for business investment: a primer for policy makers in developing countries. World Development, 30(9), 1497-1516. 